\title{
ESKi TÜRK RUNIK METINLERDEKI ESIZ ÜZERINE
}

\section{On Esiz in the Old Turkic Inscriptions}

\section{Rysbek ALIMOV*}

\section{ÖZ}

Esiz eski Türk runik yazıtlarında en sık geçen kelimelerden biridir. Divanü Lügati't-Türk'te verilen anlamına istinaden hep "yazık" şeklinde bir acınma ünlemi olarak değerlendirilen esiżin runik yazıtlarda kaydedilen çokluk ve iyelik ekli kullanımları onun ünlemleşmiş bir isim olduğunu, diğer bir deyişle acınma ünlemi işlevini sonradan kazandı̆̆ını gösterir.

Makalede esiżin ve ondan türemiş esirke- fiilinin hem tarihî, hem çağdaş Türk lehçelerindeki kullanımı ve anlam çerçevesinden hareketle onun özellikle Eski Türk runik metinlerindeki sözlüksel anlamı ortaya konulmaya çalışılmıştır.

Yazar zikrolunan kelimenin eski Türk runik yazıtlarında "değerli, kıymetli, aziz" şeklinde bir sözlüksel anlama sahip olduğu görüşündedir.

Anahtar Sözcükler: esiz, esirke-, +XrkAeki, Eski Türk runik yazıtları, Yenisey.

\section{ABSTRACT}

Esiz is one of the most frequently occurring words in the Old Turkic Runic inscriptions. Based on the meaning given in Diwanu Lughat at-Turk by al-Kashgari esiz is understood as alas, an interjection expressing sorrow, regret and compassion. However, the fact that it can be inflected with the suffixes of possession or plurality demonstrates that esiz is a noun serves as an interjection, in other words it is a secondary interjection.

The aim of this paper is to find out the initial lexical meaning of esiz. In order to do that the author uses the lexicographic data relating to esiz and its denominative form esirke- in both historical and contemporary Turkic languages.

The author claims that the lexical meaning of esiz in the Old Turkic Runic texts should be as follows: dear, valuable, worthy.

Key Words: esiz, esirke-, suffix +XrkA-, Turkic runic inscriptions, Yenisey.

\section{Giriş}

Esiz kelimesi Eski Türkçe döneminde, ekseriyetle Yenisey havzasındakiler olmak üzere pek çok runik yazıtta geçer (bk. Tekin 1964; Kormuşin 1997). Esiz ayrıca DLT, KB ve $\mathrm{AH}$ gibi Orta Türkçe metinlerinde ve Çağataycada da görülür (bk. Clauson 1971: 253b).

Söz konusu kelime bugünkü Türk lehçelerinde de yaşamaktadır. Kelime Kırgızca ve Özbekçede esiz ve sırasıyla küçültme ekli esizgana' ve esizginə şekillerinde karşımıza çıkar (bk. Yudahin 1985: 467; Karıniyazov - Borovkov 1941: 608). Aynı kelime

"Mardin Artuklu Üniversitesi, Edebiyat Fakültesi, Türk Dili ve Edebiyatı Bölümü 'Bu kullanım sözlüklerde geçmemesine rağmen, Kırgızcanın güney ağızlarında yaygındır. Zaten esiz kelimesi de ağırlıklı olarak güney ağızlarında (örn. Aksı ağzı) kullanılır. 
Uygurcada esit ve esitgiñ olarak geçer (Nacip 1968: 146b). Sonuncuda kelimenin dar önsesli ist şekli de görülür (Kibirova-Tsunvazo 1961: 86b).

Kelime DLT'nin Türkçe Atalay çevirisinde essiz ${ }^{2}$ (DLT/ll: 188) ve esiz (DLT/lll: 51) şekliyle yer alır ve anlamı "Bir kaybın arkasından üzülmeyi belirten sözcük. Arapça'daki ya esefa (yazık) ifadesine benzer." olarak verilerek esiz anı刀 yigitliki “yazık onun gençliğine" örnek cümlesiyle desteklenir. ${ }^{3}$

Esiz tarihî Türk lehçeleriyle ilgili kaynaklarda hep “yazık” şeklinde bir acınma ünlemi olarak anlamlandırılır, ancak özellikle Türk runik metinlerinde geçtiği örneklerin büyük bir kısmında önerilen bu anlamın bağlama uymadı̆̆ı dikkat çekmektedir. Bu durum aslında ilgili leksikografik çalışmalarda esiżin sahip olduğu sözlüksel anlamların eksik yansıtılmış olmasından kaynaklanmaktadır. Kelimenin bugünkü Kırgızca ve Özbekçedeki kullanımına bakıldığında esiżin bir acınma ünlemi yanı sıra temelde bir niteleme sıfatı işlevinde de kullanıldı̆̆ı görülmektedir.

Zaten özellikle Eski Türk runik metinlerinde görülen çokluk ve iyelik ekli kullanımı (örneğin: esizim, esizlerim) söz konusu kelimenin acınma ünlemi işlevini sonradan kazandığını, diğer bir deyişle sonradan ünlemleşmiş bir isim olduğunu göstermektedir. Üstelik yazıtlarda geçen çok sayıda örnekte bir tamlayan unsur olarak geçmesi, onun, ayrıca, aslî anlamını koruduğuna da işaret etmektedir.

Esiżden türeme Eski Türkçe esirke- fiilinin zengin anlam içeriğini geçmişe dönük kronolojik olarak katmanlara ayırma girişimi de kelimenin sonradan ünlem işlevi kazanmış bir isim soylu kelime olduğunu teyit etmektedir.

\section{ESIZ ISIMDEN TÜREME IKINCIL BIR ÜNLEM}

Esizín eski Türk runik metinlerinde doğru teşhisini Tekin'e borçluyuz. Tekin konuyla ilgili çalışmasında yazıtlar üzerinde çalışan araştırmacıların uzun bir süre siz, size, sizime "siz; size; benim olan size" şeklinde yanlış okudukları $A S^{2} Z, S^{2} Y Z(A)$, $\mathrm{AS}^{2} Y Z M, \mathrm{~S}^{2} Y Z M(\mathrm{~A})^{4}$ imlasıly geçen kelimeyi DLT'de geçen zikrolunan kelime ve anlamına dayanarak esiz, esiz-e, esizim, esizim-e olarak düzeltir ve "yazık" şeklinde bir acınma ünlemi olarak değerlendirir (bk. Tekin 1964: 134-144).

\footnotetext{
${ }^{2}$ Essiz şeklindeki çifte s'nin anlamı kuvvetlendirmek için (emphatic) olduğu bir önceki essiz maddesi ile yigitlik maddesindeki örnek cümleden belli olmaktadır, bu yüzden kelimenin lemması esiz'dir.

${ }^{3}$ Diğer tercümeler: essiz kalima talahhuf 'a word expressing sorrow', like yā asafā 'alas'; hence one says essiz anı̣ yigitliki; yā lahfā 'alā şabābihi 'alas for his youth' (bk. Dankoff-Kelly 1982: 143).

DLT: essiz Bir kaybın arkasından üzülmeyi belirten sözcük. Arapça'daki ya esefa (yazık) ifadesine benzer. Essiz anıg yigitliki: Yazık onun gençliğine! (bk. Erdi-Yurteser. 2005: 267).

“Слово, выражающее сожаление, подобное (арабскому) уа asafa "увы, как жаль".

Esiz aning yigitliki “Увы, где его молодость”. (bk. Awezova 2005: 171).

${ }^{4}$ Kormuşin 1997: 253'te ilk kez yayımlanan E-147'de geçen $S^{2} Z^{2}{ }^{2}{ }^{2} M$ şekli de vardır.
} 
Gerçekten de $\mathrm{AS}^{2} \mathrm{Z}, \mathrm{S}^{2} \mathrm{YZ}(\mathrm{A}), \mathrm{AS}^{2} \mathrm{YZM}, \mathrm{S}^{2} \mathrm{YZM}(\mathrm{A})$ işaret kümelerini “yazık” anlamında bir acınma ünlemi olarak değerlendirme runik yazıtların metninin daha doğru anlaşılmasına katkı sağlamıştır. Hatta Kormuşin (1997: 5) Tekin'in bu tashihini Eski Türkçe ile ilgili çok önemli metinbilimsel buluşlardan biri olarak sayar.

Eski Türk runik yazıtlarıyla ilgili çağdaş çalışmalarda söz konusu işaret kümelerini yer yer hâlâ farklı değerlendirenler olsa bile (bk. Useev 2007: 1-8; Sertkaya 2009: 231), konuyla ilgili yayın yapan araştırmacıların hemen hemen hepsi Tekin'in önerisini bütünüyle kabul etmektedir (bk. Kormuşin 1997, Kormuşin 2008, Şirin User 2011: 117-127).

Ancak Tekin'in esiz ile ilgili önerisinde, kanaatimizce, bu kelimeyle ilgili birkaç husus göz ardı edilmiştir. ilki, acınma ünleminin $A S^{2} Z, S^{2} Y Z$ yanı sıra $A S^{2} Y Z M, S^{2} Y Z M$ gibi şekillerinin de varlığıdır. Tekin runik metinlerde geçen yukarıdaki işaret kümelerini esiz ve esizim olarak okumasına rağmen, esizim'i esiz'in “muhtemelen 1. teklik şahıs iyelik ekli” genişletilmiş şekli der ve aralarındaki bariz farkı dikkate almadan anlamını yine “yazık" şeklinde verir (Tekin 1964: 134-144). Kelimenin E-147'de geçen $\mathrm{S}^{2} \mathrm{ZL}^{2} \mathrm{R}^{2} \mathrm{M}$ (e) $s(i) z l(e) r(i) m$ şeklini dikkate aldığımızda son işaretin gerçekten de 1. teklik şahıs iyelik eki olduğu belli olmaktadır. E-26 (Oçurı) yazıtındaki $\mathrm{S}^{2} \mathrm{YZD}^{5}$ (e)siz(i) $\eta$ ve Altay'daki Yabogan (A-80) yazıtında yer alan $\mathrm{S}^{2} \mathrm{ZD}(e) s(i) z(i) \eta^{6}$ işaret kümelerinden aynı kelimenin başka iyelik ekleri ${ }^{7}$ (bu durumda 2. teklik şahıs iyelik eki) de alabileceği görülmektedir (bk. sırasıyla Şirin User 2009: 170; www.altay.uni-frankfurt.de/runika_l.htm).

Bununla birlikte esiz runik metinlerin büyük bir kısmında bir tamlamanın niteleyen unsuru olarak da geçtiği görülür. Örneğin; esiz elim kanım (E-10 (=Elegest 1) yazıtı), esiz yüz elig erim... (E-45 (=Köjeelig-Hovu) yazıtı) esiz elim (Uyuk-Tarlık I) vd. (bk. Kormuşin 1997: 284).

Hem iyelik eki alabilmesi, hem tamlayan unsur olarak kullanılması söz konusu acınma ünleminin öncelikle isim soylu bir kelime olduğunu gösterir.

Tekin'in gözden kaçırdığı başka bir husus ise kelimenin anlamıyla ilgilidir. Hatırlarsak, esiz DLT'de üzüntüyü bildiren bir kelime olmakla birlikte Arapça ya esefa “yazık” kelimesinin tam karşılı̆̆ değil, bir benzeri olarak gösterilir (bk. DLT/lll: 51). KM esižin ya esefa ile anlamı bakımından değil, işlevi bakımından benzer olduğunu söyler, diğer bir deyişle ya esefa ünlemi esiżi birebir değil, mealen karşılar.

\footnotetext{
${ }^{5}$ Kormuşin E-26 yazıtının yayımında her nedense $S^{2} Y Z D$ işaret kümesinin geçtiği satıra yer vermez (bk. Kormuşin 2008: 17-18).

${ }^{6}$ Okuma makalenin yazarına aittir.

7 Sertkaya (2010: 216) E-25 (Oznaçennoye 1) yazıtı 6. satırındaki 23-26 işaretlerini $\mathrm{S}^{2} \mathrm{ZDZ}$ (e) $s(i) z(i) \eta(i) z$ şeklinde okumayı önermektedir. Bu öneriyi doğru kabul edersek söz konusu kelimenin 2. çokluk şahıs iyelik eki alabildiği ortaya çıkmaktadır. Gerçi, teorik olarak da bu zaten mümkündür.
} 
Belirtilenler esizín aslında ikincil bir ünlem olduğu fikrini pekiştirmektedir, başka bir deyişle esiz ünlem görevini sonradan üstlenen bir isim soylu kelime olarak karşımıza çıkmaktadır.

Nitekim Erdal (2004: 354) da aynı kelimenin bir ünlem ve "zavallı, acınacak" anlamına gelen isim olarak kullanıldığını belirtir ve yukarıda örnek olarak verdiğimiz E45/7'deki esiz yüz elig erim... ibaresini "my poor 150 men..." diye tercüme eder.

Ancak, Erdal esiżin isim olarak değerlendirmesini kabul etmesine rağmen, bu özelliğinin aslî olduğunu söylemez. Oysa yukarıda da belirttiğimiz gibi, kelimenin iyelik eki alabilmesi ve tamlayan unsur olarak kullanılması doğrudan buna işaret eder.

Çağdaş Türk lehçelerine baktığımız zaman bu şekilde ortaya çıkmış çok sayıda ünlemin var olduğu görülür. Örneğin: TT. efendim (< efendi+m (1. teklik şahıs iyelik eki), canım (< can+(1)m (1. teklik şahıs iyelik eki), anam (< ana+m (1. teklik şahıs iyelik eki), oğlum (< oğul+(u)m (1. teklik şahıs iyelik eki); Kaz., Kırg. ve Özb. ilayım "inşallah" $(<$ ilah+(1)m (1. teklik şahıs iyelik eki), ya pirim "genellikle yaşlı insanlar oturduğu yerden kalkarken kullandıkları ünlem (< yâ pir "pir”+(i)m (1. teklik şahıs iyelik eki); Tuv. dadayım "eyvah" (< daday "korku, ürperti”+(1)m (1. teklik şahıs iyelik eki), kırım sınar "vallahi billahi" (< kır "dirsek"+(i)m (1. teklik şahıs iyelik eki (birebir anlamı: dirseğim kırılsın).

Bu örnekler köken itibariyle isim olan, fakat belirli bağlamda kullanıldığında yalnızca duygu bildirme işlevi edinen ikincil veya türemiş ünlemlerdir. Buna göre esiz ve onun 1. teklik şahıs iyelik ekli esizim ve çoklu esizlerim şekilleri işlevi yönüyle aynı ünlemler kategorisinde değerlendirilmelidir.

\section{ESIZIN ANLAMI}

Üzerinde durduğumuz kelimeyle ilgili başka bir mesele onun sözlük anlamıla ilgilidir. Yukarıda da belirttiğimiz gibi Tekin kelimeyi her durumda “yazık” şeklinde anlamlandırır. Tekin'in ilgili çalışmasından sonra Eski Türk yazıtlarıyla ilgili yayımlarda da araştırmacıların hemen hemen hepsi onun görüşünü aynen kabul eder. Örneğin, Kormuşin yazıtlardaki esiżi “увы, жаль (yazık, keder)”, esizim ve esizlerimi farklı eklere sahip olmasına rağmen “жаль мне (yazık bana)” şeklinde anlamlandırır (bk. Kormuşin 1997).

Bazı dilciler ise geçtiği bağlama istinaden esiz için farklı anlamlar önerir. Erdal (2004: 354), örneğin, kelimeyi kederlenme, hayıflanma bildiren bir ünlem olmakla birlikte yazıtlarda "acınacak, zavallı" anlamında bir isim olarak da kullanıldığını söyler. Roux (1983: 146) ise söz konusu kelimeyi malheur "talihsizlik, keder", iyelik ekli şeklini (essizim) ise mon malheur "talihsizliğim, kederim" şeklinde tercüme eder. Hamilton (1986: 216) Eski Uygurca metinlerde de geçen söz konusu kelimeyi benzer şekilde malheur, malheureux, mauvais, hélas "talihsizlik, talihsiz, kötü, yazık" olarak anlamlandırır.

Konuyla ilgili görüşlere esiz’in işlev itibariyle bir acınma ünlemi olduğu hususunda katılmakla birlikte, semantik çerçevesiyle ilgili beyan edilen görüşlerin 
hiçbirinin kelimenin aslî sözlük anlamına ilişkin olmadığını, tümünün yalnızca üstlendiği işlev dolayısıyla esiz için araştırmacılar tarafindan uygun bulunan birer yakıştırmadan ibaret olduğunu belirtmemizde yarar vardır.

Konuya açıklık getirmek adına yukarıda bahsi geçen ikincil ünlemlere dönelim. TT. efendim örneğinde, kelimenin temel anlamını efendi unvanı oluşturur, ancak dilde üstlendiği görevi itibariyle anlamları (a) bir sesleniş karşısında "buradayım" anlamında kullanılan, (b) anlaşılmayan bir sözü tekrarlatmak için söylenen, (c) karşı çıkma, paylama cümlesini pekiştirmek için söylenen birer ünlemdir. Aynı şekilde TT. anam da (a) kadın erkek, büyük küçük herkese karşı kullanılan teklifsiz bir seslenme şeklinde ve (b) sese verilen tona göre şaşma, beğenme, acı, üzüntü gibi duygular anlatan ünlem olarak karşımıza çıkar, ancak bu ünlemin temelinde "ana, anne" şeklindeki aslî bir anlam yatmaktadır. Tuv. dadayım' in birebir tercümesi "benim korkum” iken, işlevi dolayısıyla sahip olduğu anlam "eyvah" şeklinde bir ünlemdir.

Esiz'e gelince, onun verdiğimiz örneklere benzemekle birlikte onlardan farklı yönleri de söz konusudur. ilki, Türk runik metinlerinde çoğu kez bir tamlamanın niteleyen unsuru olarak geçmesi, diğeri ise yukarıda da belirttiğim gibi hem çokluk, hem (örneklere bakılırsa şimdilik 1. ve 2 . şahıs) iyelik eki alabildiğidir.

Bu durum kelimenin işlevi dolayısıyla edindiği deploratif anlamın yanı sıra Eski Türk runik metinlerinde kısmen veya tamamen aslî sözlük anlamını da koruduğuna ve aynı zamanda o anlamda kullanıldığına da işaret etmektedir.

Peki, ünlem özelliğini sonradan kazanmış olan isim soylu esiżin Eski Türk runik yazıtlarında kullanılan sözlük anlamı nedir? Bunun için bir taraftan kelimenin yaşayan Türk lehçelerindeki durumunun, diğer taraftan ise ondan türemiş olan esirke- fiilinin ele alınması gerekir.

\section{3. ÇAĞDAŞ TÜRK LEHÇELERINDE ESIZ}

Esiz, yukarıda da belirtildiği gibi, çağdaş Türk lehçelerinden sadece Kırgızca, Özbekçe ve Uygurcada görülür. Ne var ki, bu lehçeler ile ilgili leksikografik çalışmaların çoğunda mezkûr kelime bir lemma olarak yer almaz. Geçtiği sözlüklerde de esiz'in sahip olduğu anlamların tam olarak yansıtılmadığı görülür. Sözlükçülerin esiżi göz ardı etmeleri, esasında, kelimenin kullanım alanının sınırı ve bilhassa arkaik oluşu gibi nesnel ve o dillerin konuşurları arasında esiżin denotatif değil, daha çok konotatif anlamının yaygın olması gibi öznel etkenlere de bağlıdır. Buna rağmen, özellikle Kırgızca ve Özbekçe esiz'in aslî sözlük anlamını ortaya çıkarmak için yeterli malzeme sunmaktadır.

\subsection{ESIZIN KIRGIZCADAKI ANLAMI}

Esiz Kırgızca sözlüklerin büyük bir kısmında maddebaşı olarak yer almaz (bk. örneğin KTTS 1969; KTS 2010). Yudahin'in sözlügüunde söz konusu kelimeye yer verilmesine rağmen, anlamı için esil şeklinde başka bir lemmaya gönderme yapılmaktadır: 
Эсиз то же, что эсил; эсиз жан то же, что эсил жан.

[Esiz esil ile ayni; esiz can eşittir esil can. ] (Yudahin 1988: 341).

Эсил горемычный, бедненький, болезный; эсил баш бедная головушка; эсил жан горемычная душа; эсил энең бейтаалай твоя горемычная несчастная мать; эсил кайран выражение, употребляемое мужчинами при оплакивании умершего.

Esil: mihnetkeş (ömrünü kaygı ve kederle geçiren); zavallı, gariban. Esil baş zavallı kimse; Esil can zavall can; Esil eney beytaalay talihsiz zavall annen; Esil kayran ölü için ağlarken erkeklerce kullanılan tabir.] (Yudahin 1988: 341).

Görüldüğü üzere, Kırgızcada esiżin başka bir acınma ünlemi olan esil ile sadece eş anlamlı değil, her yönüyle eşdeğer olduğu söylenmektedir. Gerçekten de kullanım sıklığı bakımından ilkinin diğerine kıyasla daha pasif durumda olması dışında, yaptığımız gözlemler Kırgızcada zikrolunan iki kelimenin birbirinin yerini tamamıla tutabildiğini göstermiştir. Bu husus esiz ile esil kelimelerinin Kırgızcada birer leksiko-semantik dublet olduğuna işarettir ${ }^{8}$.

Bununla birlikte Kırgızcadaki kullanımına bakıldığında Yudahin'in sözlüğünde esil kelimesinin sahip olduğu anlamların tam olarak yansıtılmadığı da ortaya çıkmaktadır (bk. Egemberdiyeva-Akmataliyev 2002: 186, 260 ve 365; Jaynakova 1997: 46, 141; Kırbaşev 1996: 191 ve 194). Kırgızca Kococaş destanından alınan aşağıdaki satırlarda, örneğin, esiżin asıl (< Ar. aṣ) "aziz, değerli, kıymetli” kelimesiyle eşanlamlı olduğu görülmektedir.

Кокуй күн, эне, ыйлаба,

Эсил жаның кыйнаба

Алат күн, ата, ыйлаба,

Асыл жаның кыйнаба.

[Eyvah, anam ağlama

Değerli canına eziyet etme

Eyvah, babam ağlama

Kıymetli canına eziyet etme] (Kırbaşev 1996: 191)

\footnotetext{
${ }^{8}$ Kırgızca esilin Türk runik metinlerindeki $(\mathrm{A}) \mathrm{S}^{2} \mathrm{YN}^{2}(\mathrm{Y})$ (e) $\sin (i)$ acınma ünlemi olduğu görüşü için bk. Alimov 2008: 35-48. ET. esiz ve esin(i) kelimelerinin her ikisinin de bugünkü Kırgızcadaki esiz ve esilde olduğu gibi iyelik ekleri alabilmesi ve tamlanan unsur olarak kullanılması onların leksiko-semantik dublet özelliklerinin henüz ET. dönemine dayandı̆̆ına işaret etmektedir. Aynı zamanda fonetik benzerliği onların kökteş kelimeler olabileceğini düşündürmektedir.
} 
Gerçi, Yudahin de sözlüğündeki örneklerin birinde asıl kayran ikilemesinin esil kayran ile aynı olduğunu belirtmekte ve dolaylı da olsa esilin diğer kelimeye ait yukarıdaki anlamlara sahip olduğunu kabul etmektedir ${ }^{9}$ (bk. Yudahin 1988: 76).

Yine Kococaş destanında geçen aşağıdaki örnekte esil kelimesinin 2. teklik iyelik eki aldığı ve yukarıdaki örnekte olduğu gibi "aziz, değerli, kıymetli" anlamında kullanıldığı görülmektedir:

Эсиңе ал, сен Зулайка,

Эсилиң, мерген парыңды.

[Züleyha, sen hep hatırla

Kıymetlin (olan) avcı eşini] (Kırbaşev 1996: 143)

Semetey destanında ise kelime aynı anlamda 1. teklik iyelik ekli şekliyle ortaya çıkar:

\section{Эсилим эжем кебимди ук}

[Azizim teyzem, sözümü dinle] (Karalayev 1987: 156)

Esiżin sahip olduğu anlamlarla ilgili Yudahin'in sözlüğündeki bu eksiklik Kırgızcanın bir başka akademik sözlüğünde giderilmiştir:

Эсил 1. кайран, чиркин, өткөн; 2. киши өлгөндө өкүнүч иретинде айтылуучу сөз; 2. ыйык, аялуу, таза. Эсил энекем айткан кеп эле. Семетей

[Esil ı. zavallı, acıklı, gariban; 2. Biri öldüğünde üzüntü bildirmek için söylenen ünlem; 3. Mukaddes, değerli, nezih. Kıymetli anneciğimin sözüydü bu. (Semetey)] (KTS 2010: 1439).

Son sözlükte esiz maddebaşı olarak yer almaz, ancak, buna rağmen, görülmektedir ki esil ve dolayısıyla esiz, Kırgızcada yalnızca deploratif özellikli bir ünlem ile hayıflanma içerikli "zavallı, acıklı, gariban" anlamına değil, aynı zamanda "aziz, değerli, kıymetli” şeklinde müspet anlamlara da sahiptir. Hatta yukarıdaki kaynaklar sonuncu anlamının diğerlerine kıyasla daha öncül olduğuna işaret etmektedir. Nitekim Jaynakova derlediği folklor malzemelerine dayanarak esil için “zavallı, gariban; yazık” değil, yalnızca "aziz, değerli, nezih” anlamını vermektedir (Jaynakova 1997: 141).

Burada ayrıca esil kelimesinin Kazakçada da geçtiğini ve kullanımı ve sahip olduğu anlamlar bakımından Kırgızcadaki ile birebir örtüştüğünü belirtmek de yerinde olacaktır (bk. Budagov 1869: 194a; Alimov 2008: 35-48).

${ }^{9} \mathrm{Her}$ ne kadar asıl ve esil kelimeleri şeklen benzese de bunlar kökteş değildir, kelimelerin sahip olduğu anlamlar ve kullanımlarını dikkate aldığımızda Ar. aṣl > esil ses olayı söz konusu olamaz. 
Kırgızcadaki esiz'in anlam çerçevesini belirginleștirmede esile ilaveten istifade edilebilecek kayran şeklinde bir başka kelime daha vardır. Moğolca bir ödünçleme olan kayran, söz konusu ikilinin her biriyle birer ikileme (hendiadys) oluşturmakla birlikte, esiz ve esilin kullanıldığı her durumda onların yerini istisnasız tutabilen eşdeğer özellikte başka bir kelimedir. Hatta Özbekçedeki esizgina'ya karşılık Kırgızca (ve Kazakçada) şeklen küçültme, anlamca pekiştirme bildiren + gana ekini de alabilmektedir. Örneğin: Özbekçede esizgina yasşligim, Kırgızcada ise kayrangana (=esizgana) caştıgım.

Yudahin'in sözlügünde kayran kelimesinin anlamları şu şekilde açıklanmaktadır:

Кайран (обычно употребляется с оттенком соболезнования) милый, дорогой; горемычный; кайран башым моя бедная головушка; кайран эр арманда кетти бедный молодец, рано он умер; жаманга айткан кайран сөз погов. как жаль слов, сказанных дурному; Аккула жандан кайранбы? Аккула дороже жизни? (Аккула-самый знаменитый и самый дорогой конь, но он все же не дороже собственной жизни); кайран акча жок болду! плакали денежки!; эсил кайран см. эсил.

[Kayran (mutat olduğu üzere, acınma edasılla kullanılır) : değerli, kıymetli; zavallı. Kayran başım zavallı başım; Kayran er armanda ketti zavallı öldü ve gözü arkada kaldı; Camanga aytkan kayran söz kötü adama söylenen söze yazık; Akkula candan kayranbı? Akkula candan daha mı kıymetli? (Akkula, şüphesiz en meşhur ve en değerli attır, ancak can ondan daha da değerlidir.); Kayran akça cok boldu! Yazık, gitti paralar!; Esil kayran bk. esil.] (bk. Yudahin 1985: 321).

Kırgızca leksikografik çalışmalarda esil ve kayran kelimeleriyle ilgili verilen anlamları onlarla kullanım ve işlevi bakımından eşdeğer olan esiz'e de tamamıyla atfetmek mümkün olduğundan, son kelimenin bir kimse veya nesnenin ardından hayıflanma bildiren bir sıfat ve ünlem anlamı yanı sıra "değerli, kıymetli" şeklinde bir anlamının var olduğu bir kez daha ortaya çıkmaktadır, hatta, yukarıda esil ile ilgili olarak belirttiğimiz gibi, bu anlamın aslî olduğu, söz konusu kelimelerin "zavallı" ve "yazık" anlamlarının kelimenin acınma, hayıflanma gibi kendine has bağlamındaki kullanımından kaynaklandığı anlaşılmaktadır". Diğer bir deyişle kelimenin "değerli, kıymetli, aziz" anlamı denotatif, "zavallı; yazı"” anlamları ise konotatif anlamlardır. Örneğin, yukarıdaki kayran akça cok boldu ibaresinin birebir tercümesi "değerli para yok oldu" şeklindedir, ancak hayıflanma söz konusu olduğu için mealen "paranın değerini bilemedik, yazık oldu” veya Yudahin'in önerdiği gibi “yazık, gitti paralar” anlamı çıkmaktadır.

\footnotetext{
${ }^{10}$ Kayran'ın "değerli, kıymetli” anlamının öncül olduğu Moğolcadaki durumundan belli olmaktadır. Kelimenin aynı anlamlara sahip Moğolcadaki şekli xairan ile xaira "love, grace, mercy, compassion" kökteş olup, bunlardan +tay ekiyle xairatai (hayrtay) "beloved, favorite, darling, loving" ve $+l A$ - ekiyle xairala- "to love, to have mercy, to take care of" kelimeleri türemiştir (bk. Lessing 1960: 913ab; ekler için ayrıca Poppe 1987: 166-167).
} 
Çağdaş Kırgızca metinlerde esiz' e hemen hemen hiç rastlanmaz, zira yukarıda da belirttiğimiz gibi, mezkûr kelime bir taraftan arkaik, diğer taraftan ise ağız özelliklidir. Ancak 19 yy. Kırgız şairlerinden Molla Niyaz'ın şiirlerinde esiz birçok kez karşımıza çıkar. Üstelik içinde geçtiği bağlamdan anlamının "aziz, değerli, kıymetli” şseklinde müspet çağrışımlı olduğu hemen anlaşılmaktadır. Örneğin:

el dävläti esiz er

er Migbaydan baş ket(t)i (33/51)

öldürüldü."

"Halkın serveti değerli bahadır(lar)dır (ve böylelerden biri olan) Mịbay

atıdan tüşüp zōr boldu

esiz bekler qōr boldu

atadan qalıp zōr boldu

azamat bekler qōr boldu (13a/6-9) (bk. Narmamatova 2010: 228, 285).

"Değerli beyler atsız kaldı, müşkül durumda bırakıldılar ve hor hakir oldular. Babayiğit beyler babasız kaldı, müşkül durumda bırakıldılar ve hor hakir oldular.”

Esiz maddebaşı olarak Kırgızca ağız sözlüklerinde de yer almaz (bk. Bakinova 1956, Mukambayev 2009 vd.). Ancak Kırgızcanın güney ağızlarında, özellikle Alabuka ve Aksı'da "aziz, değerli, kıymetli" anlamında kullanıldığına alan çalışması sırasında makalenin yazarı tanık olmuştur. Örneğin:

Munog̀u esiz buyumdardı taştabay özüyer menen ala ketkile emi.

"Şu değerli eşyaları bırakmayın, gittiğinizde beraberinizde götürün.”

Mınday işke esiz canın ḳynawayt onojuz özü.

"Kendisi böyle bir iş için kıymetli canına eziyet etmez ki."

Her ne kadar sözlüklere aksettirilmemiş de olsa esiżin son üç örnek ve leksikosemantik dubleti olan esil ve kayran'ın sahip olduğu anlam çerçevesi dikkate alındığında Kırgızcada "aziz, değerli, kıymetli" anlamlarına sahip olduğu belli olmaktadır. Üstelik esil ve kayrarida olduğu gibi, sonuncu anlamın aslında kelimenin öncül anlamı olduğunu söylemek de mümkündür.

\subsection{ESIZIN ÖZBEKÇEDEKI ANLAMI}

Özbekçe leksikografik çalışmalarda esiz bir lemma olarak Kırgızca sözlüklere kıyasla daha yaygındır. Ancak geçtiği çoğu sözlükte anlamı yalnızca "yazık” şeklinde bir acınma ünlemi olarak verilir (örneğin, bk. Yusuf 1993: 364). Karı-Niyazov ve Borovkov'un hazırladığı Özbekçe-Rusça sözlükte ise esiz maddesi daha geniş ve açıklayıcıdır: 
Эсиз І. бедняжка, бедняга; 2. как жаль! Эсизки буни билмадим Как жаль, что я не мог этого узнать.

Эсизгина то же что эсиз.

[Esiz ı. Zavallı, gariban; 2. Yazık! Esizki buni bilmadim Yazık! Bunu bilemedim.

Esizgina esiz ile aynı] (bk. Karı-Niyazov - Borovkov 1941: 608).

Özbekçe akademik sözlükte ise söz konusu kelimenin anlamları şu şekilde gösterilmektedir:

Эсиз 1. аттанг, эйвох, афсус; 2. афсуски; 3. увол, хайф

[Esiz l. yazık, eyvah; 2. ne yazık ki, maalesef; 2. zavallı, acıkl; ziyan, günah] (bk. ÖTiL: 453a).

Görüldüğü gibi, esiżin Özbekçedeki anlamları onun Kırgızcadaki durumuyla uyuşmakta ve temelde kaybı söz konusu bir kimse veya nesneyle ilgili hayıflanma bildirmek için kullanıldı̆̆ görülmektedir.

Özbekçede, esiżin Kırgızcada görülen esil ve kayran șeklindeki leksiko-semantik dubletleri görülmez, ancak Özbekçedeki esiżin Kırgızca ve Kazakçadaki esil ve kayran'ın karşılı̆̆ olarak kullanıldığı aşağıdaki örneklerden belli olmaktadır. Kırgızca өлгөнгө ыйлаган кайран (vеуа эсилАсиз) көз, акмакка айткан кайран (vеуа эсилАсиз) сөз" atasözü Kazakçada өлікке жылаван есіл (veуа қ̧айран) көзім, наданzа қ̧ор болван есіл (vеуа құайран) сөзім,' nodonga so'zlagan esiz so'zim ${ }^{13}$ şeklinde görülür.

Bu durum benzer bağlamda, üstelik aynı kelimelerle birlikte kullanılıyor olması sebebiyle Kırgızcada esil ve kayran aracılığılla esize atfedilen anlamların, ister istemez, Özbekçe esiz için de geçerli olduğunu düşündürmektedir.

Esiżin anlamın belirginleştirmek için diğer taraftan "zavallı, gariban, biçare" anlamına gelen bir başka kelime olan bechoràyı (< Far. bî-çâra "çaresiz") benzer örnekte kullanmak yeterlidir. Özbekçede, örneğin, bechora odam tabiri tam olarak "biçare, zavall, gariban kimse" anlamına gelirken, esiz odam ifadesi "değerli olup da hak ettiği değeri alamayan bir kimse" veya "-mış olamayacak kadar değerli bir kimse" şeklinde bir anlam ayrıntısına sahiptir. Bu aslında Lessing'in Kırgızca ve Kazakçada görülen kayran

\footnotetext{
"Birebir çevirisi "Ölene ağlayan değerli gözüm, ahmağa söylediğim değerli sözüm", mealen çevirisi ise "ölü için ağlayan gözlerime, ahmağa söylediğim sözüme yazık" şeklindedir.

${ }^{12}$ Birebir çevirisi "ölüye ağlayan değerli gözüm, cahile ziyan ettiğim değerli sözüm”, mealen çevirisi ise "ölü için ağlayan gözlerime, cahile söylediğim değerli sözüme yazık" şeklindedir. Kazakçada ayrıca bu atasözünün жыламасқ̧а жылаван екі көзім, тыңцамасқ̧а сөйлеген есіл сөзім varyantı da vardır.

${ }^{13}$ Birebir çevirisi “ölüye ağladığım esiz gözüm, cahile söylediğim esiz sözüm”, mealen çevirisi ise "ölü için döktüğüm göz yaşıma, cahil için sarf ettiğim sözüme yazık” şeklindedir.
} 
için de geçerli olan Moğolca aslına ait "a thing that is too good to be ..." anlamını hatırlatmaktadır (bk. Lessing 1960: 913b). Aşağıdaki Özbekçe atasözünde de sonuncu anlam ayrıntısı daha da belirgin hale gelmektedir: Qo'shniga bersam esiz oshim, üyda tursa sasir oshim. Mealen "Komşuya versem de, evde kalsa da yazık bu yemeğe" anlama sahip bu atasözünün birebir tercümesi aslında "Komşuya verilmeyecek kadar değerli olan, evde kaldığında ise kokacak olan yemeğim"dir.

Esiz'in Özbekçe sözlüklerde yansıtılan “yazık, eyvah; zavallı” şeklinde deploratif anlamı, Kırgızca ile ilgili belirttiğimiz gibi kelimenin hayıflanma ve teessüf konulu sınırlı bir bağlamda kullanılmasından kaynaklanmaktadır, diğer bir deyişle yukarıdaki anlamlar kelimenin işlevi dolayısıyla edindiği konotatif anlamlardır. Son örneklerde geçen “-mış olamayacak kadar değerli” anlam ayrıntısı aslında esiżin bir kez daha başlangıçta "değerli, kıymetli" anlamlarına sahip olduğuna işaret etmektedir.

\section{ESKI TÜRKÇE ESIRKE- FiiLi VE ANLAMı}

\subsection{ESIRKE- FIiLININ KÖKENI}

Esiżin anlamını belirginleştirmek için yararlanabileceğimiz diğer bir kelime de ondan türemiş ET. esirke- fiilidir. Türkçenin tarihî devirlerinde, örneğin, EUyg. äzirgä-, isirke-, Çăg. ésirge-, MKıpç. ve OsmT. esirge-, çağdaş Türk lehçelerinden ise, örneğin, Kaz. ve Kklp. 'iesirke-, TT. esirge-, Çuv. azărxa- şeklinde kaydedilen ve arketipi esirkeolan fiil (ayrıntılı bilgi için bk. ESTYa 1/310) çok zengin semantik içeriğe sahiptir (bk.4.3.3).

Kökenine ilişkin görüşler temelde iki gruba ayrılabilir. ilkine göre, kelimenin kökeni $+(X) r k A$ - ekiyle genişlemiş * es "hafiza, bellek, anı, düşünce" ismine bağlanır. Bu görüşü ilk öne süren Bang ve Gabain (1930: 210) *es "Gedachtnis (hafiza, şuur)" konusunda ihtiyatlı yaklaşım sergilerken, Levitskaya (1976: 179-180) ve Hamilton (1998: 116 , 190. not) ET. esirke- fiilinin es "hafıza, şuur, anı, düşünce" $+(X) r k A$ - yapısından türediğinden emindirler. Sevortyan ise bu etimolojinin muhtemel olduğunu söylemekte birlikte ekin bağlandığı kök tam olarak tespit edilmeden bunun güvenilir olmadığı görüşündedir (bk. ESTYa 1/310). Clauson da fiilin bir isimden türediğini konusunda öncekilerle hemfikir olmakla birlikte kelimenin kökeni konusunda "semantik olarak bilinen herhangi bir *es kelimesiyle ilgili değil” diye ihtiyatlı davranarak somut öneride bulunmamıştır (Clauson 1972: 252b). Tekin (2003: 88) öncekilerden biraz farklı davranarak ET. esirke- fiilinin *äs *äas (> Yak. ät, iät “yazık”) +(X)rkA yapısından türediğini söyler.

Diğer görüşe göre, ET. esirke- fiili esiżden türemiştir. Tezcan (1981: 178), örneğin, fiilin kökenini esirke- < esiz + addan eylem türeten + ${ }^{\circ} r G A-$ eki (releşme, Rothasismus ile) olarak vermektedir. Erdal (1991: 363) da esirke- < esiz $+(X) r k A-$ şeklinde benzer görüş bildirir.

Aslında, AT. rotasizm olayıyla birlikte, örneğin, Kırgızca esirke- (= ET. ésiz 'kötü, kem, aksi" $+(X) r k A-)$ "şarhoş olmak; (şarhoşluk sebebiyle) farfaralık etmek, taşkınlık etmek", cabırka- (= ET. yabız "kötü, fena” +(X)rkA-) “zorbalığa maruz kalmak, zarar 
görmek, zaiyat vermek" ve sırka- (= ET. sız (> Alt. sis) “yanma sesi, ağrı” $+(X) r k A-)$ "hastalanmak" ve TT. (ağız.) tedirgemek (< ET. tėtiz "nahoş, çirkin" $+(X) r k A-)$ "rahatsız olmak, tedirgin olmak" kelimelerinin kökeni dikkate alındığında bile esiz ile ilgili Tezcan ve Erdal'ın önerilerinin doğruluğu hemen teyit edilmekte ve fiilin kökeniyle ilgili tereddütler ortadan kalkmaktadır.

ET. esiżin isim soylu bir kelime olduğu bağlandığı $+(X) r k A$ - ekinden dolayı da belli olmaktadır. Bu durumda esiż in yalın sözlüksel anlamının tespiti için ET. esirkefiilinin başlangıç anlamının (initial meaning) tespit edilmesi zorunlu görünmektedir. Bunun için kelimenin semantik çerçevesinden hareketle geriye dönük kronolojik anlam gelişmesinin ortaya konulması gerekir. Ancak öncelikle esiżin fiilleşirken ona kattığı anlamı belirlemek için $+(X) r k A$ - ekinin işlevi üzerinde durulmalıdır.

\section{2. $+(X) R K A-$ EKi VE işLEVi}

$+(X) r k A$ - eki Türkçe ve Moğolca için ortak olan arkaik eklerden biridir. Doerfer'e göre bu ekin iki dildeki benzerliği tesadüfîdir (bk. Erdal 1991: 463). Erdal (1991: 463) ekin her iki dildeki işlevinde görülen bir takım benzerliklere işaret etmekle birlikte Moğolca ekin isimlerden fiil, Türkçe ekin ise hem isimlerden, hem de fiillerden fiil türettiğini iddia ederek Doerfer'in görüşünü desteklediğini ima eder. Ramstedt (1912: 35) ve ardından Rassadin (1980: 25, 39) ekin Moğolca kökenli olduğunu ve birçok diğer morfolojik göstergelerle birlikte Türkçeye nüfuz ettiğini söyler. Bunun aksine Şçerbak (1997: 224) aynı eki Halha Moğolcası ve Buryatçada üretken bir ek haline dönüşen Türkçe unsur olarak görür.

Clauson (1959: 174-187), Clark (1977: 110-168) ve Şçerbak'ın (1997: 189) somut örneklerle savundukları "XIIl. yy. öncesine kadar Moğolcadan Türkçeye değil morfolojik gösterge, kelimelerin bile alıntılanmasının söz konusu olmadığı" görüşü ekin Türkçe kökenli olma ihtimalini artırmaktadır.

Diğer taraftan $+(X) r k A$ - eki Moğol dillerinin güney kolunu temsil eden Baoanca (bk. Todayeva 1964: 66-69) ile Dunsyancada (bk. Todayeva 1971: 39-41), ayrıca Kidan kolunu temsil eden Dagurcada (bk. Todayeva 1986: 78-80) yer almadı̆̆ı, bunun aksine, söz konusu ekin Şçerbak'ın (1997: 224) ve Chuluu'nun (1998: 62-64) da işaret ettiği üzere tarih boyunca konuşurlarının Türk kavimleriyle sıkı temaslarda bulunduğu Halha Moğolcası ve Buryatça gibi Kuzey Moğol dillerinde aktif kullanıldığı gerçeği dikkate alınırsa, ekin bu dillerde Türkçeden alıntılanmış bir morfolojik unsur olduğu kendiliğinden ortaya çıkar.

Çok sayıda fiilin bünyesinde geçmesine rağmen, mezkûr ek Türkçede, genel olarak, günümüzde pek üretken değildir. ${ }^{14} \mathrm{Bu}$ yüzden ilgili gramer çalışmalarında genellikle ya hiç yer almaz (örneğin bk. SiGTYa III), ya da izah edilmeden, üretken olmayan eklerden biri olarak verilir (bk. örneğin, Kononov 1956: 263, Balakayev vd. 1962: 266-267). Hakasça ile ilgili dil çalışmalarındaki durum bu bakımdan özetleyici

${ }^{14}$ Türk dillerinin birçoğunda Moğolca alıntılar arasında $+(X) r k A$ - eki bulunduran fiiller de vardır (örneğin bk. Rassadin 1980: 25, 39 vd.). 
niteliktedir, aslında. Diğer Türk lehçelerine kıyasla çok daha fazla kelimede geçmesine rağmen, ilgili ilk gramer çalışmasında bu eke birkaç örnekle de olsa yer verilir, oysa daha sonraki kapsamlı akademik çalışmada ekle ilgili herhangi bir bilgi yer almaz (bk. sırasıyla Baskakov - İnkijekova-Grekul 1953: 420; Baskakov 1975: 164-170).

Çağdaş Türk lehçelerinde $+(X) r k A$ - ekinin işleviyle ilgili açıklayıcı bilgi veren birkaç çalışmadan biri İshakov ve Palmbah'a aittir. Tuvacada ünsüzlerden sonra ırga-, i:rge-, u:rga-, ü:rge-, ünlülerden sonra ise 1 rga-, irge-, urga-, ürge- şeklinde geçen mezkûr ekin geçişli ve geçişsiz fiiller türettiğini ve fiile "kendini (veya başka birini) ... saymak", "gibi görünmek" ve "bağlandığı isme ait bir özellik göstermek" anlamları kattığını belirtirler ve uluurga- "kendini övmek, büyütmek” < ulug “büyük, ulu”, biliirge"kendini bilir sanmak; bilgisiyle mağrurlanmak" < bilig "bilgi”, adırga- "böbürlenmek, kibirlenmek" < at "ad, isim" gibi örnekler verirler (İshakov - Palmbah 1961: 269-270). Banguoğlu (1974: 213) ise ekin eskiden beri yaygın olmadığına işaret etmekle birlikte Türkiye Türkçesinde "bir tür benzerlik (gibi saymak, gibi davranmak) anlamı taşıyan fiiller" oluşturduğunu ve “ $+(X) m s A$ - şeklinde diğer bir isimden fiil türeten ekle anlamdaş (azırgamak = azımsamak)" olduğunu belirtir.

Erdal (1991: 458-465) ET. $+(X) r k A-$ ekinin, bağlandı̆̆ı gövdenin ister bir duygunun, isterse hakkında tutum sahibi olunan şeyin veya tutumun zihinsel kaynağının adı olsun, hep duygu ve his bildirmek için kullanıldığını söyler. Erdal, ayrıca, bazı örneklerde $-(X) n$ - dönüşlülük ekiyle genişlemesine rağmen, ekin genellikle geçişli fiiller oluşturduğu görüşündedir.

Diğer taraftan Poppe (1954: 66) Moğolcada geçen aynı ekin, türettiği fiile "bir şeye çokça sahip olma" anlamı kattığı söyler ve şu örnekleri verir: bayarka- "sahip olduğu zenginlikten dolayı gururlanmak" < bayan "zengin"; omorka- "gururlu olmak" < omog "gurur"; çilegerke- "hasta olmak" < çilegen "hastalık, rahatsızlık", ecerke- "birine kendi kurallarını dayatmak" < ecen "üstat".

Chuluu (1998: 62-64) ise ekin “... şekilde davranmak”, “...gibi hareket etmek” anlamlarına sahip olduğunu ve bağlandığı kelime kökünün anlamıyla doğrudan ilgili geçişsiz fiiller türettiğini belirtir.

Araştırmacılar arasında $+(X) r k A$ - ekinin işlevi konusunda da bir görüş birliği yoktur, ancak çoğunluk her iki dilde de ekin işlevinin genellikle "... gibi davranmak" olduğu konusunda hemfikirdir. Ancak, örneğin, Kırg. cabırka- (< ET. yabız "kötü, fena" + (X)rkA-) "zorbalığa maruz kalmak, zarar görmek, zayiat vermek", küçürkö- (küç "güç" + $(X) r k A-)$ "ağrımak", TT. daşırga- (< daş “taş" + $(X) r k A-)$ "hayvanın ayağını taş aşındırıp, acıtırak hayvan yürüyememek", Tuv. adırga- (< at "ad” + $(X) r k A-)$ "böbürlenmek, kibirlenmek", çıdırga- "(< çıt "koku” +(X)rkA-) "koku almak, koku hissetmek”, aynı şekilde Moğ. yekerke- (< yeke "büyük” + (X)rkA-) "büyük olmak”, sonirka- (< sonin "ilginç, garip" $+(X) r k A-)$ "meraklı olmak" örneklerine bakıldığında eke atfedilen anlamın bu fiillere pek uymadığı görülmektedir.

Aynı zamanda $+(X) r k A$ - ekli aynı fiillerin farklı lehçelere göre birçok durumda anlam yönüyle de birbirinden farklı olduğu göze çarpmaktadır. Örneğin, Tuv. azırga(n)- 
şeklindeki fiil "kendini az görmek, kendini küçümsemek" anlamındayken (İshakovPalmbah 1961: 269), TT. (ağız.) azırga- (< az "az" + (X)rkA-) fiili "bir şeyi az görmek" anlamındadır, Kırg. cabırḳa- "zorbalığa maruz kalmak, zarar görmek, zaiyat vermek" anlamında, oysa Kaz. jabirḳa- "bezmek, bunalmak" (Kenesbayev 1959: 200a) anlamındadır. Yine Hak. ulurḩa- (< ulug "büyük, ulu” $+(X) r k A-)$ "kendini büyük görmek, kendisiyle böbürlenmek" (Rassadin 1980: 39) anlamındayken, Alt. ulurka- "(başka birini) büyük görmek, (başka birini) saymak" (Rassadin 1980: 26) anlamındadır. Kırg. açuurkan- "acı veya ekşi bir şeyi gereğinden fazla tükettikten sonra rahatsızlık hissetmek, acı hissetmek" (Levitskaya 1976: 180) anlamıdayken, Tuv. acırkan- "bir şeyi çok fazla acılı (tuzlu, ekşili) bulmak; acılı (ekşili, tuzlu) bir şeye karşı yüzünü buruşturmak" (ishakov-Palmbah 1961: 269) anlamındadır.

Bünyesinde bulunduğu aynı fiillere kattığı anlamın dil ve lehçelere göre tutarsızlık ve farklılık göstermesi aslında ekin kendisiyle ilgili bir durum değildir. Bu, ancak $+(X) r k A$ - ekli fiillerin bir taraftan eskiliği, diğer taraftan ise her birinin bağımsız olarak zamanla yerel anlam değişmelerine uğramış olmasıyla ilgilidir. Üstelik bu anlam değişmeleri, üzerinde durduğumuz esirge- fiilinde görüldüğü üzere, dillere göre birkaç kademeli olabilir, diğer bir deyişle kelimenin anlamı bir dilde sabit kalırken, diğer bir dilde bir yere kadar gelişir, bir başka dilde ise daha ileri bir yerdedir. ${ }^{15}$

Buna göre, Tuv. ve TT. azırga- fiilinin anlamı başta ortak olmalıdır, ancak Tuv.da dönüşlülük eki alarak (azırga(n)-) hareketin özneye dönük olduğunu pekiştirirken, TT.de aynı fiil geçişli hale gelmiştir. Hak. ulurḩa- öncül anlamındayken, aynı fiil Alt.da ilerlemiş bir anlama sahiptir. Kırg. Aksı ağzında cıtırka- (< ET. yıd "koku" $+(X) r k A-)$ "(elbise gibi şeylere) başka bir şeyin (örneğin, ter) kokusu sinmek” (şahsi gözlem) iken, aynı kelime bilahare Kırg. güney ağızlarında “(bir şeyi) koklamak” anlamı kazanmıştır (Yudahin 1985: 285). Son anlam üstelik Tuv. için de geçerlidir (bk. İshakov-Palmbah 1961: 269).

Temel işlevini ortaya çıkarmak için öncelikle $+(X) r k A$ - ekinin geçişli mi, yoksa geçişsiz mi filler türettiğini belirlemekte yarar vardır. Hatırlarsak, Erdal (1991: 458) ekin ET.de genellikle geçişli, İshakov-Palmbah (1961: 269) ise Tuv. için hem geçişli, hem geçişsiz, DTS (1969: 655) ise ET. için, bazı örnekler hariç, geçişsiz olduğunu belirtir. Chuluu (1998: 62-64) da ekin Moğ. için geçişsiz fiiller türettiği görüşündedir. Tutarsızlık aslında, yukarıda da belirttiğimiz gibi, $+(X) r k A$ - ekli fiillerin semantik gelişimindeki duraksama ve ilerlemelerden kaynaklanmaktadır. Bir kısım fiillerde anlam değişirken, diğerlerinde öncül anlam korunmaktadır.

Ancak ekin hem tarihî, hem çağdaş Türk lehçelerinde yalnızca $-(X)$ n- dönüşlülük ekiyle genişletilebildiğini ve bunun $+(X) r k A$ - ekinin özneye dönük hareket bildirmek anlamını pekiştirmek olduğunu kabul edersek, üzerinde durduğumuz ekin isimden

\footnotetext{
${ }^{15}$ ET. yazuk (yaz- "yoldan şaşmak" - (u)k) kelimesi bu tür semantik gelişime en iyi örnektir: hata, kusur, suç (ET. Hak. Alt. Kırg. Kaz.) > günah (Kırg., Kaz., Uyg. Tat.) > günahkar, behbaht (Kum., Nog., AzT. vd.) > zavallı (Kum., Trkm., AzT.) > acınma ünlemi (TT., AzT., Gag.) (bk. ESTYa/IV: 72-73).
} 
geçişsiz fiiller türettiğini söyleyebiliriz. Tarihî ve çağdaş Türk dillerinde geçen $+(X) r k A-$ ekli fiillerin topluca tahlili de ayrıca bu görüşü desteklemektedir.

Üstelik örneklerin tümü temelde $+(X) r k A$ - ekinin "bir olayın veya bir durumun etkisinde bulunmak (olmak), maruz bulunmak (olmak)" anlamlı fiiller oluşturduğunu da göstermişstir. Örneğin, birçok Türk lehçesinde bulunan taşırḳa- daşırgáa- fiilinin sahip olduğu "hayvanın ayağını taş aşındırıp, acıtırak hayvan yürüyememek" aslında "taşa maruz kalmak” anlamından gelişmiştir. Kırg. (güney ağız.) cıtırka- "koklamak” < Kırg. (Aksı ağız.) “(elbise gibi şeylere) başka bir şeyin (örneğin, ter) kokusu sinmek” < "kokuya maruz bulunmak" şeklindedir. Yine Kırg. küçürkö- (küç "güç" $+(X) r k A-)$ fiilin "ağrımak" anlamı "ağrıya maruz kalmak, ağrının etkisi altında olmak" anlamından gelişmiştir. Alt. ulurḳa- “(başka birini) büyük görmek, (başka birini) saymak” fiilindeki anlam gelişiminin bir önceki halini de Hak. muâdili ulurḩa- "kendini büyük görmek, kendisiyle böbürlenmek" fiilinde görmekteyiz. Sonuncu anlamın da $+(X) r k A$ - ekinin ulug "büyük, ulu" ismine kazandırmış olduğu "büyüklük etkisi altında bulunmak" anlamından gelişmiş olduğu ortadadır.

ET. tsoyurḳa- “acımak, merhamet duymak, şefkat göstermek” fiilinin köken

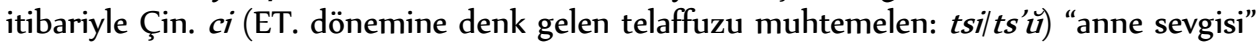
(DTS: 583b, 655b), "şefkat, merhamet" (Gabain 1950: 344a) ismine dayandı̆̆ bilinmektedir, bu fiilin anlamındaki dönüşüm ancak "anne sevgisi (veya şefkat ve merhamet) etkisi altında bulunmak" > "acımak, merhamet duymak, şefkat göstermek" olmalıdır.

Moğolcadaki örneklerin büyük çoğunluğu da ekin bu işleve sahip olduğunu kanıtlamaktadır. Örneğin, bayarḳa- fiilinin "sahip olduğu zenginlikten dolayı gururlanmak" anlamı "zenginliğin etkisinde bulunmak"tan, çilegerke- fiilinin "hasta olmak" anlamı "hastalığa maruz olmak"tan, ecerke- fiilinin "birine kendi kurallarını dayatmak" anlamı da "üstatlık etkisinde bulunmak"tan kaynaklanmaktadır.

Bu durumda, $+(X) r k A$ - ekinin temelde isimden geçişsiz fiiller türettiğini ve işlevinin de fiile "bir olayın veya bir durumun etkisinde bulunmak (olmak), maruz bulunmak (olmak)” anlamı katmak olduğu ortaya çıkmaktadır.

\subsection{ESIRKE- FiiLIN BAŞLANGIÇ ANLAMI}

Sevortyan ET. esirke- fiilinin günümüz Türk lehçelerindeki semantik gelişimini şu katmanlara ayırmaktadır: 1) acımak, eseflenmek; merhamet etmek; aynı acıyı hissetmek, esirgemek; 2) korumak, muhafaza etmek, himaye etmek; bakmak, ilgilenmek; 3) kıskanmak, esirgemek, biri şeyi vermeyi veya yapmayı istememek, çok görmek, çekinmek; 4) kaçınmak, içtinap etmek; 5) üzülmek, keyfi kaçmak, kederlenmek, esef etmek (geniş bilgi için bk. ESTYa/l: 310, ayrıca bk. Arslan Erol 2008: 277). Ne var ki, bu sıralama kelimenin anlam gelişiminin kronolojisini yansıtmamaktadır. Oysa bizim için önemli olan esiżin anlamını belirginleştirmek için söz konusu fiilin başlangıç anlamını tespit etmektir. 
ET. esirke- fiilinin başlangıç anlamı konusunda şu görüşler vardır. Tezcan (1981: 178) ET. esiz için önerilen "yazık" anlamından hareketle ET. esirke-fiilinin anlamının ilk olarak "yazık saymak" > "acımak" yönünde geliştiğini söyler. Clauson (197ı: 252b) ise fiilin ilk anlamının açıkça "teessüf etmek" olduğunu iddia eder ve bu anlamın iki zıt yönde geliştiğini ve bunların da (1) “(birine) acımak”; (2) “(bir şeyi) paylaşmaktan üzülmek; birine bir şeyi çok görmek, kıskanmak” olduğunu belirtir. Erdal, bunun aksine, esirke- fiilinin hiçbir zaman "acımak" anlamına gelmediğini, onun yalnızca "bir kimse veya nesnenin (kaçınılmaz ve koşulsuz) kaybından dolayı üzülmek” şeklinde bir anlama sahip olduğunu savunur. Bununla birlikte "kaybından dolayı üzüntü duyulanın bir kimse olduğu durumda, söyleyenin ilgili duruma duyarlılığının müspet olduğunu, bunun aksine kaybedilenin bir nesne olduğu durumda ise fiilin "kıskanmak" şeklinde menfi çağrışıma büründüğünü ilave eder (bk. Erdal 1991: 459).

Tarihî Türk lehçelerine de baktığımızda söz konusu fiilin Erdal'ın da belirttiği gibi temelde iki anlamı göze çarpmaktadır: ilki "kaybından dolayı üzülmek, eseflenmek" (bk. ol esirgedi neyni “O, bir şeyin kaybı nedeniyle üzüntü duydu” DLT 1/306), diğeri de "kıskanmak, çok görmek, esirgemek” (bk. mana beş yüz yaratmak äsirgäyür sän "Bana beş yüz parayı çok görüyorsun.” (Maitr. 1.13); özịe esirker saran öz neநin, kişike kaçan birge aygıl tẹin "Cimri bir kimse kendi eşyasını kendinden bile kıskanırken bir başkasına elindekinin yarısını nasıl versin ki, sen söyle.” KB 950. beyit).

Ancak KB Viyana nüshasındaki sözüm bu usal bolma ay kadaş, esirke tiriglik yava kılma yaş "Ey dost, sözüm şudur; aymaz olma ve hayatını koru (hayatının değerini bil), yıllarını heba etme" (173/29 beyit) parçasına baktığımızda esirke- fiilinin aynı dönemde "korumak, muhafaza etmek" anlamı da olduğu ortaya çıkmaktadır. ${ }^{16}$ Nitekim Radloff da esirke- fiilinin ET'de aynı anlama sahip olduğunu söyler (bk. Radloff 1893: 896). Fiilin EAT metinlerinde de "korumak, himaye etmek, muhafaza etmek, siyanet etmek" anlamlarına sahip olduğunu kabul edersek (bk. ESTYa/l: 310; Arslan Erol 2008: 277) üzerinde durduğumuz fiilin başlangıç anlamıla ilgili önerilen görüşler şüpheli görünmektedir. Zaten söz konusu önerilere dayanarak esirke-fiilinin bugünkü zengin semantik çerçevesinin kronolojik gelişimini takip etmek de mümkün değildir. Üstelik verilen örneklerde $+(X) r k A$ - ekinin işlevinin aksine esirke- fiili geçişlidir ve ekin ona katması gereken "bir olayın veya bir durumun etkisinde bulunmak (olmak), maruz bulunmak (olmak)" anlamı da hissedilmemektedir.

Bu durum yukarıda önerilen anlamlardan hiçbirinin esirke- fiilinin başlangıç anlamıyla ilgili olmadığını göstermektedir, diğer bir deyişle zikrolunan fiilin DLT'deki “kaybından dolayı üzülmek”, KB'deki “kıskanmak, çok görmek” ve "korumak” anlamları zikrolunan fiilin başlangıç anlamından gelişen tali anlamlardır.

Yalnızca yukarıda zikredilen sahip olduğu anlamlardan yola çıkarak esirke-fiilinin semantiğinin kronolojik dizinini ortaya koymak mümkün olmamaktadır. Bu yüzden fiilin

${ }^{16} \mathrm{~KB}$ Viyana nüshasındaki esirke- yerine Fergana ve Mısır nüshalarında (6087. beyit) esizke- yer alır, ancak sonuncu kelime bağlama uymamaktadır, bu yüzden istinsah hatası olmalıdır. Asıl metinde geçen kelime, kanaatimizce, esirke- fiilidir. 
başlangıç anlamını ortaya çıkarmak için fiili oluşturan esiz ve onun çağdaş Türk lehçelerinde kayıtlı "değerli, kıymetli, aziz" anlamından istifade edilmesi gerekir.

$\mathrm{Bu}$ durumda $+(X) r k A$ - ekin işlevini ve onun fiile kattığı "bir olayın veya bir durumun etkisinde bulunmak (olmak), maruz bulunmak (olmak)" anlam ayrıntısını da dikkate alırsak karşımıza şöyle bir anlam ortaya çıkar: "değerli olmaya maruz kalmak (veya değerli olmak)."

Buna göre de kelimenin sahip olduğu anlamların kronolojik sıralaması şu şekilde gelişmiş olmalıdır: 1. değerli olmak $\rightarrow$ değerli olduğu için korumak $\rightarrow$ korumak, muhafaza etmek, siyanet etmek $\rightarrow$ himaye etmek, merhamet etmek $\rightarrow$ a) acımak; b) bakmak, yetiştirmek, büyütmek, beslemek, hayrına desteklemek; 2. değerli olmak $\rightarrow$ (bir şey (örn., kayıp, hediye, hibe vs.)) olamayacak kadar değerli olmak $\rightarrow$ kıyamamak, razı olmamak $\rightarrow$ a) eseflenmek, kaybından dolayı üzülmek; b) çok görmek, kıskanmak.

Esirke- fiilinin önerilen silsiledeki başlangıç anlamları ET. öncesine ait olmalıdır, zira Türk runik yazıtlarında bile artık onun E-29/4'teki ...bodun es(i)rk(ä)yür $m(\ddot{a})$ n...ibaresinde olduğu gibi “eseflenmek, kaybından dolayı üzülmek” anlamı söz konusudur (bk. Erdal 1991: 460). Zaten bünyesinde AT. rotasizm olayının varlığı üzerinde durduğumuz fiilin semantiğindeki dağılımın henüz ET. öncesi başladığı belli olmaktadır.

\section{Sonuç}

Esiżin bugünkü Kırgızca ve Özbekçedeki anlamlarıyla ondan türemiş ET. esirkefiilinin başlangıç anlamına dayanarak Eski Türk runik yazıtlarındaki sözlüksel anlamının "değerli, kıymetli, aziz" olduğunu söyleyebiliriz.

Bununla birlikte esizín, hem tarihî, hem çağdaş Türk lehçelerinde ister sıfat, ister acınma ünlemi işlevinde olsun, örneklerin baskın çoğunluğunda hayıflanma edasıyla kullanıldığının da unutulmaması gerekir.

Kanaatimizce, esiz "değerli, kıymetli $\rightarrow$ zavallı, esef edilecek (deploratif bağlamda sınırı anlam kötüleşmesi) $\rightarrow$ yazık (ünlem; leksik anlamın kaybolması) şeklinde bir anlam değişmesine maruz kalmıştır. Bununla birlikte kelimenin ilk anlamının denotatif, diğer anlamlarının ise konotatif özellikli olduğu da unutulmamalıdır.

Kelimenin geçtiği yazıtların büyük çoğunluğunun birer mezar yazıtı olması ve içeriğinin hayıflanma, kederlenme ve acınma ile dolu olması ister istemez örneklerin bir kısmında esiżi mealen "yazık” ve benzeri bir acınma ünlemi ile karşılamamızı zorunlu kılabilir. Ancak çoğu örnekte, özellikle esiz'in tamlayan unsur olarak geçtiği parçalarda onu “aziz, değerli, kıymetli” kelimeleriyle karşılamak daha doğrudur. Nitekim E-42/7'de geçen esiz yerim iduk yerim... parçasında esiżin bir deploratif ünlem işlevinde kullanılması düşünülemez, çünkü burada esiz yerim ile ıduk yerim ibareleri arasında bir paralellik söz konusudur ve bu pasaj da ancak "aziz yerim, kutsal yerim” şeklinde tercüme edilebilir. 
Bunun gibi kelimenin iyelik ekli şekilleri de benzer şekilde anlamlandırmalıdır: esizim "kıymetlim, azizim”, esizlerim “kıymetlilerim, azizlerim”, esizin "kıymetlin, azizin”.

Sonuç olarak ilgili kelimelerin geçtiği tüm Türk runik yazıtları metinlerinin buradaki öneriler doğrultusunda tekrar gözden geçirilmesi gerektiği ortaya çıkmaktadır.

\section{KISALTMALAR}

$\begin{array}{ll}\text { AH } & \text { Atabetü’l-Hakayık } \\ \text { Alt. } & \text { Altayca } \\ \text { Ar. } & \text { Arapça } \\ \text { AT. } & \text { Ana Türk.e } \\ \text { Çağ. } & \text { Çağatayca } \\ \text { Çuv. } & \text { Çuvaşça } \\ \text { DLT } & \text { Divanü Lügati't-Türk } \\ \text { Hak. } & \text { Hakasça } \\ \text { E-29 } & \text { Yenisey Bölgesi 29 numaralı yazıt } \\ \text { E-42 } & \text { Yenisey Bölgesi 42 numaralı yazıt } \\ \text { E-147 } & \text { Yenisey Bölgesi 147 numaralı yazıt } \\ \text { EAT } & \text { Eski Anadolu Türkçesi } \\ \text { ET. } & \text { Eski Türkçe } \\ \text { ESTYa Etimologiçeskiy Slovar Tyurkskih Yazıkov } \\ \text { EUyg. Eski Uygurca } \\ \text { Far. } \\ \text { Kaz. } & \text { Farsça } \\ \text { Kklp. } & \text { Kazakça } \\ \text { Kırg. } & \text { Karakalpakça } \\ \text { KB } & \text { Kırgızca } \\ \text { KTTS Kırgız Tilinin Tüşündürmö Sözdügü } \\ \text { KTS } & \text { Kurgız Tilinin Sözdügü } \\ \text { Maitr. Maitrisimit } \\ \text { MKıpç. } & \text { Memlük Kıpçakçası } \\ \text { Moğ. } & \text { Moğolca } \\ \text { OsmT.Osmanlı Türkçesi } \\ \text { ÖTil } & \text { Özbek Tilining İzåhli Lügati } \\ \text { Özb. } & \text { Özbekçe } \\ \text { SiGTYa } & \text { Sravnitelno-istoriçeskiya Grammatika Tyurkskih Yazıkov } \\ \text { TT. } & \text { Türkiye Türkçesi } \\ \text { Tuv. } & \text { Tuvaca } \\ \end{array}$




\section{KAYNAKÇA}

ABDULlAYEV, E. ve iSAYEV, D. (haz.). Kırgız Tilinin Tüşündürmö Sözdügü, Frunze: Mektep, 1969.

ARSLAN-EROL, H., Eski Türkçeden Eski Anadolu Türkçesine Anlam Değişmeleri, Ankara: Türk Dil Kurumu Yayınları, 2008.

ATALAY, B. (çev.). Divanü Lugat-it-Türk Tercümesi. Cilt I- IV, Ankara: TDK, 1939 - 1941.

AWEZOVA, Z. A. (haz.). Mahmud al-Kaşgari. Divan Lugat at-Turk, Almatı: Dayk-Press, 2005.

BAKINOVA, G. (1956) Kırgız Tilinin Oş Govorloru, Frunze: Kırgız SSR ilimder Akademiyası Til jana Adabiyat Institutu Basması

BALAKAYEV M. B. ve diğer. Sovremennıy Kazahskiy Yazık. Fonetika i Morfologiya, Alma-Ata: Izdatelstvo Akademii Nauk Kazahskoy SSR, 1962.

BANG, W. ve GABAIN von A. "Türkische Turfan-Texte III", Sitzungsberichte der Preussischen Akademie der Wissenschaften (SPAW) Philosophisch-Historische Klasse, 1930/13, s. 183-211.

BANG, W. ve GABAIN von A. "Analytischer Index zu den fünf ersten Stücken der Türkischen Turfan-Texte", Sitzungsberichte der Preussischen Akademie der Wissenschaften (SPAW) Philosophisch-Historische Klasse, 1931/17, s. 461-517.

BANGUOĞLU, T. Türkçenin Grameri, İstanbul: Baha Matbaası, 1974.

BASKAKOV, N. A. (haz.). Grammatika Hakasskogo Yazıka, Moskva: Nauka, 1975.

BASKAKOV, N. A. İnkijekova-Grekul. Hakasskiy Yazık (Fonetiçeskaya Struktura, Slovarnıy Sostav i Grammatiçeskiy Stroy), Moskva: Glavizdat Ministerstva Kulturı SSSR, 1953.

BUDAGOV, L. Sravnitelnıy slovar turetsko-tatarskih nareçiy so vklyuçeniyem upotrebitelneyşih slov arabskih $i$ persidskih $i$ s perevodom na russkiy yazık, Tom $l$ I ${ }_{-}$, Sankpeterburg: Tipografiya İmperatorskoy Akademii Nauk, 1869.

VASILYEV, D. D. Korpus tyurkskih runiçeskih pamyatnikov basseyna Yeniseya, Leningrad: Nauka, 1983:

CHULUU, U. Studies on Mongolian Verb Morphology. A thesis submitted in conformity with the requirments for the degree of Doctor of Philosophy, Graduate Department of East Asian Studies, University of Toronto, 1998.

CLARK, L. V. "Mongol Elements in Old Turkic?", Journal de la Société Finno-Ougrienne 75 (1977), Helsinki, s. 110-168

CLAUSON, G. "The Earliest Turkish Loan Words in Mongolian", Central Asiatic Journal, IV/3 (1959), Wiesbaden, s. 174-187.

GABAIN von A. Alttürkische Grammatik, Leipzig: Otto Harrassowitz, 1950.

EGEMBERDiYEVA S. ve AKMATALiYEV A. (haz.) Tarıhıy Irlar. Koşoktor cana Okuyalar, Bişkek: Şam Basması, 2002.

ERDAL, M. Old Turkic word formation: A functional approach to the lexicon, Wiesbaden: Harrassowitz, 1991.

ERDAL, M. A Grammar of Old Turkic, Leiden-Boston: Brill, 2004.

ERDi S. ve YURTSEVER S. T. Kaşgarlı Mahmud, Divanü Lügati't-Türk. Çeviri, Uyarlama, Düzenleme, İstanbul: Kabalcı Yayınları, 2005.

HAMILTON, J. Manuscrits Ouigours $d u I X^{e}-X^{e}$ Siècle de Touen Houang, Tome 1, Paris: Peeters, 1986.

HAMILTIN, J. (çev. Köken, V.) Buddhacılığa ilişkin Lygurca el yazması. lyi ve kötü prens öyküsü, Ankara: Türk Dil Kurumu Yayınları, 1998.

JAYNAKOVA A. (haz.) Sarinci Bököy - Cayıl Mırza, Bişkek: Şam Basması, 1998.

iSHAKOV, F. G. Ve PALMBAH, A. A. Grammatika Tuvinskogo Yazıka. Fonetika i Morfologiya, Moskva: İzdatelstvo Vostoçnoy Literaturı, 1961. 
KARINIYAZOV, T. N. ve BOROVKOV, A. K. Uzbeksko-Russkiy Slovar, Taşkent: İdatelstvo Uzb. Filiala Akademii Nauk SSSR, 1941.

KENESBAYEV i. K. (haz.) Kazak Tilinin Tüsindirme Sözdigi, ı. Tom, A-K, Almatı: Kazak SSR Gılım Akademiyasını Baspası, 1959.

KIRBAŞEV K. (haz.) Koşocaş, Bişkek: Şam Basması, 1996.

Kırgız Tilinin Sözdügü, Bişkek: Kırgızistan ilimder Akademiyası Til ve Adabiyat İnstitutu, 2010.

KONONOV, A. N. Grammatika Sovremennogo Turetskogo Literaturnogo Yazıka, MoskvaLeningrad: İzdatelstvo Akademii Nauk SSSR, 1956.

KORMUŞiN, i. Tyukskiye Yeniseyskiye Epitafii. Tekstı i Issledovaniya, Moskva: Nauka, 1997.

KORMUŞiN, i. Tyukskiye Yeniseyskiye Epitafii. Grammatika i Tekstologiya, Moskva: Nauka, 2008.

LESSING, F. D. Mongolian-English Dictionary, Berkeley-Los Angeles: University of California Press, 1960.

Lessing, F. D. (çev. Karaağaç, G.) Moğolca-Türkçe Sözlük $2 O-C(Z)$, Ankara: TDK Yayınları, 2003.

LEVITSKAYA, L. S. Istoriçeskaya Morfologiya Çuvaşskogo Yazıka, Moskva: Nauka, 1976.

MUKAMBAYEV, C. Kırgız Tilinin Dialektologiyalık Sözdügü, Bişkek: Manas Universiteti Basması, 2009.

DANKOFF R. ve KELLY J. Mahmūd al-Kāšy̆yar Compendium of The Turkic Dialects (Dīvānu Lun'ät at-Turk). Edited and translated with introduction and indices by R. Dankoff in colloboration with James Kelly Part I, Boston: Harvard University Press, 1982.

POPPE, N. Grammar of Written Mongolian, Wiesbaden: Otto Harrassowitz, 1954.

POPPE, N. Introduction to Mongolian Comparative Studies, Helsinki: Finno-Ugrian Society, 1987.

RADLOFF W. Opıt Slovarya Tyurkskih Nareçiy, Tom Perviy, Glasniye. Versuch der Wörterbuches der Türk-Dialecte, Erster Band, die Vocale, Sanktpeterburg. Tipografiya İmperatorskoy Akademi Nauk, 1893.

RAMSTEDT, G. J. "Zur Verbstammbildungslehre der mongolisch-türkischen Sprachen”, Journal de la Société Finno-Ougrienne, XXV111/3 (1912), Helsingfors.

RASSADiN, V. i. Mongolo-Buryatskiye Zaimstvovaniya v Sibirskih Tyurkskih Yazıkah, Moskva: Nauka, 1980.

ROUX J. P. "Le vocabulaire de la mort chez les anciens Turcs", Ural-Altaische Jahrbucher, Neue Folge, Band 3 (1983), s. 134-149.

ŞÇERBAK, A. M. Ranniye Tyurksko-Mongolskiye Yazıkovıye Svyazi (VIII-XIV vv.), SanktPeterburg, İdatelstvo İnstituta Lingvistiçeskih İssledovaniy RAN, 1997.

ŞiRiN USER, H. Re-reading and re-interpretation of some of the Yenisei inscriptions, Acta Orientalia Academiae Scientiarum Hungarium, 2011/2 (64), s. 117-127.

TEKIN, T. "On a Misinterpreted Word in the Old Turkic Inscriptions", Ural-Altaische Jahrbücher, Band 35 (1964), s. 134-144.

TEKIN, T. "The representation of Proto-Turkic Medial and Final /s/ in Yakut", Makaleler I. Altaistik (haz. Yılmaz E. ve Demir N.), Ankara: Grafiker Yayınları, 2003.

TEZCAN S. "Kutadgu Bilig dizini üzerine", Türk Dili Araştırmaları Yıllığı-Belleten, XLV/2 (Nisan 1981), say1 178, s. 23-78.

TODAYEVA B. H. Baoanskiy Yazık, Moskva: Nauka, 1964.

TODAYEVA B. H. Dagurskiy Yazık, Moskva: Nauka, 1986.

TODAYEVA B. H. Dunsyanskiy Yazık, Moskva: İzdatelstvo Vostoçnoy Literaturı, $197 ı$.

YUDAHIN, K. Kırgızca-Orusça Sözdük. Kirgizsko-Russkiy Slovar, Moskva: Sovyetskaya Ensiklopediya, 1985.

YUDAHiN, K. Kırgız Sözlüğ̈̈ (çev. Taymas, A.), cilt 1 (A-J), 2. baskı, Ankara: TDK Yayınları, 1988.

YUSUF, B. Türkça-Özbekça va Özbekça-Türkça Lügat, Taşkent: Özbekistan, 1993. 
NARMAMATOVA, G. Moldo Niyazdın Çıgarmaları: Transkripsiya, Orfografiyalık, Fonetikalık, Leksiko-Semantikalık Taldoo, Manas Üniversitesi Yayınlanmamış Doktora Tezi, 2010.

KiBiROVA, Ş. ve TSUNVAZO, Yu. Uygursko-Russkiy Yazık, Alma Ata: İzdatelstvo Akademii Nauk Kazahskoy SSR, 1961.

USEEV, N. “Esizime mi? Sizime mi?” Atatürk Üniversitesi Türkiyat Araştırmaları Enstütüsü Dergisi, sayı 34 (2007), s. 1-8.

SERTKAYA, O. F. "Yenisey yazitlarından 10, 25, 41, 51, 70, 109 ve 110 üzerine etimolojik açıklamalar ve düzeltmeler", I. Uluslararası Uzak Asya'dan Ön Asya'ya Eski Türkçe Bilgi Söleni Bildiri Metinleri, 18-20 Kasım 2009, Afyonkarahisar, s. 227-238.

NADjiP, E. Uygursko-Russkiy Slovar, Moskova: Nauka, 1968.

Sravnitelno-İstoriçeskaya Grammatika Tyurkskih Yazıkov III. Morfologiya, Moskva: Nauka, 1988.

www.altay.uni-frankfurt.de/runika_l.htm (05.05.2012)

http://www.bizdin.kg/elib/kitepter/html/semetey/semetey_skl/sectionl7.html\#titlel9 (05.05.2012) 